\title{
PENGARUH FUNGISIDA BERBAHAN AKTIF ASAM KLORO BROMO ISOSIANURIK TERHADAP INTENSITAS PENYAKIT BLAS, HAWAR PELEPAH DAUN DAN BERCAK DAUN CERCOSPORA PADA TANAMAN PADI DI GADINGREJO, PRINGSEWU
}

\author{
Pendi Setiawan, Titik Nur Aeny \& Efri \\ Jurusan Agroteknologi, Fakultas Pertanian Universitas Lampung \\ Jl.Prof. Soemantri Brodjonegoro, No.1, Bandar Lampung 35145 \\ E-mail: pendisetiawan1989@gmail.com
}

\begin{abstract}
ABSTRAK
Padi (Oryza sativa L.) merupakan tanaman penghasil beras yang menjadi makanan pokok bagi hampir seluruh penduduk di Indonesia. Salah satu kendala dalam budidaya padi adalah karena serangan berbagai macam cendawan, diantaranya cendawan Pyricularia oryzae Cav. (penyebab penyakit blas), cendawan Rhizoctonia solani Khun. (penyebab penyakit hawar pelepah daun) dan cendawan Cercospora oryzae Miyake. (penyebab penyakit bercak daun cercospora). Salah satu pengendalian yang dapat dilakukan adalah penggunaan fungisida sintetik. Penelitian ini dilakukan untuk mengetahui pengaruh fungisida berbahan aktif asam kloro bromo isosianurik terhadap intensitas penyakit blas, hawar pelepah daun dan bercak daun cercospora pada tanaman padi. Penelitian ini dilaksanakan di Desa Wonodadi, Kecamatan Gadingrejo, Kabupaten Pringsewu, Lampung, pada bulan Desember 2012 sampai dengan Juni 2013. Perlakuan dalam percobaan ini disusun dalam rancangan acak kelompok (RAK) dengan empat perlakuan dan empat kelompok. Data yang diperoleh dianalisis menggunakan sidik ragam dan nilai tengah masing-masing perlakuan diuji dengan uji BNT pada taraf 5\%. Hasil penelitian menunjukkan bahwa aplikasi fungisida berbahan aktif asam kloro bromo isosianurik efektif menekan intensitas penyakit blas leher dan penyakit hawar pelepah daun, tetapi tidak efektif dalam menekan intensitas penyakit blas daun dan penyakit bercak daun cercospora pada tanaman padi varietas Ciherang di Lampung. Tingkat konsentrasi fungisida yang efektif dalam menekan intensitas penyakit blas leher adalah 0,$5 ; 1,0$; dan 1,5 $\mathrm{g} \mathrm{L}^{-1}$, sedangkan tingkat konsentrasi fungisida yang efektif menekan intensitas penyakit hawar pelepah daun adalah $1,0 \mathrm{~g} \mathrm{~L}^{-1}$ dan $1,5 \mathrm{~g} \mathrm{~L}^{-1}$. Tidak ada perbedaan yang nyata antar tingkat konsentasi terhadap intensitas penyakitpenyakit tersebut.
\end{abstract}

Kata kunci : asam kloro bromo isosiaurik, blas, hawar pelepah, bercak daun cercospora, intensitas penyakit.

\section{PENDAHULUAN}

Padi (Oryza sativa L.) merupakan tanaman penghasil beras yang telah lama menjadi makanan pokok bagi sebagian besar penduduk dunia. Di Indonesia, sekitar $90 \%$ penduduknya masih mengonsumsi beras sebagai bahan makanan pokok. Oleh karena itu Indonesia masih harus melakukan impor beras untuk mencukupi kebutuhan pangan dalam negeri (Suparyono dan Setyono, 2004 dalam Dahyar et al). Tanaman padi di Indonesia pada umumnya tidak dapat berproduksi secara optimal karena berbagai faktor, salah satunya adalah karena adanya serangan berbagai macam organisme penyebab penyakit, diantaranya adalah penyakit blas yang disebabkan oleh cendawan Pyricularia oryzae Cav., penyakit hawar pelepah daun yang disebabkan oleh cendawan Rhizoctonia solani Khun. dan penyakit bercak daun cercospora disebabkan oleh cendawan Cercospora oryzae Miyake (Semangun, 2004).

Salah satu cara pengendalian penyakit tanaman padi yang banyak digunakan adalah dengan menggunakan fungisida sintetik. Meskipun telah diketahui bahwa penggunaan fungisida sintetik dapat menyebabkan pencemaran lingkungan, tetapi fungisida sintetik masih sering digunakan karena pertimbangan waktu. Aplikasi fungisida sintetik pada umumnya menunjukkan pengaruh yang lebih cepat dalam menghambat perkembangan penyakit (Djojosumarto, 2000). Asam kloro bromo isosianurik merupakan salah satu senyawa kimia yang dapat digunakan sebagai bahan aktif pestisida untuk mengendalikan penyakit tanaman. Senyawa kimia ini pada awalnya digunakan sebagai mikrobiosida (Kegley et al., 2010) dan selanjutnya juga digunakan sebagai bahan aktif fungisida untuk mengendalikan cendawan Colletotrichum 
gloesporiodes (Anonim, 2010). Penelitian ini dilakukan untuk menguji keefektifan bahan kimia ini terhadap intensitas penyakit blas, hawar pelepah daun dan bercak daun cercospora pada pertanaman padi di Desa Wonodadi, Kecamatan Gadingrejo, Kabupaten Pringsewu, Lampung.

\section{BAHAN DAN METODE}

Penelitian ini dilaksanakan di lahan pertanaman padi sawah di Desa Wonodadi, Kecamatan Gadingrejo, Kabupaten Pringsewu, Lampung. Penelitian ini dilaksanakan pada bulan Desember 2012 sampai dengan Juni 2013. Perlakuan dalam percobaan ini disusun menggunakan Rancangan Acak Kelompok (RAK) dengan empat kelompok yang ditentukan berdasarkan lokasinya. Perlakuan terdiri atas empat taraf konsentrasi formulasi bakterisida, yaitu kontrol (P0), konsentrasi 0,5 $\mathrm{g} \mathrm{L}^{-1}(\mathrm{P} 1)$, konsentrasi $1 \mathrm{~g} \mathrm{~L}^{-1}(\mathrm{P} 2)$ dan konsentrasi 1,5 $\mathrm{g} \mathrm{L}^{-1}(\mathrm{P} 3)$. Setiap petak perlakuan berukuran $\pm 8 \mathrm{~m} \mathrm{x}$ $10 \mathrm{~m}$, sehingga total luasan petak percobaan adalah 1280 $\mathrm{m}^{2}$. Setiap petak perlakuan ditentukan secara acak pada masing-masing kelompok. Data yang diperoleh dianalisis dengan sidik ragam. Nilai tengah masing-masing perlakuan diuji dengan uji BNT pada taraf nyata $5 \%$.

Varietas padi yang digunakan adalah varietas Ciherang. Penanaman padi dilakukan dengan menggunakan jarak tanam $25 \mathrm{~cm} \times 25 \mathrm{~cm}$, dengan sistem tanam jajar legowo (6:1). Pupuk yang digunakan adalah pupuk Urea dan $\mathrm{KCl}$ dengan dosis Urea sebanyak 50 $\mathrm{kg}$ ha ${ }^{1}$ dan $\mathrm{KCl}$ sebanyak $100 \mathrm{~kg}$ ha ${ }^{1}$ (untuk satu kali pemupukan). Pemupukan dilakukan sebanyak dua kali dalam satu musim tanam dengan dosis yang sama. Pengendalian hama dilakukann secara kimiawi sesuai dengan kebutuhan dan pengendalian gulma dilakukan secara manual. Aplikasi fungisida dilakukan sebanyak tiga kali yaitu pada saat 14, 28 dan 42 hari setelah tanam. Volume semprot yang digunakan adalah $350 \mathrm{~L} \mathrm{ha}^{-1}$.

Pengamatan pertama dilakukan pada saat tanaman padi berumur 13 hst (satu hari sebelum dilakukan aplikasi pertama) dan pengamatan selanjutnya dilakukan setiap minggu secara berkala selama satu musim tanam.
Penentuan terok dilakukan secara acak dengan metode undian. Penerokan dilakukan dengan mengamati 10 rumpun yang ditetapkan secara acak dalam setiap petak percobaan. Unit terok adalah satu rumpun padi yang terdiri dari beberapa individu tanaman padi. Pengamatan pada semua unit terok dilakukan setiap minggu untuk mengetahui intensitas penyakit yang dihitung dengan menggunakan rumus.

\section{Keterjadian Penyakit}

Keterangan :

$$
\mathrm{KT}=\frac{\mathrm{a}}{\mathrm{b}} \times 100 \%
$$

$\mathrm{KT}=$ Keterjadian penyaki

$\mathrm{a}=$ Jumlah rumpun yang terseran

$\mathrm{b}=$ Jumlah rumpun yang diamati

\section{Keparahan Penyakit}

$$
\mathrm{KP}=\frac{\sum(\mathrm{n} \times \mathrm{v})}{\mathrm{N} \times \mathrm{Z}} \times 100 \%
$$

Keterangan :

$\mathrm{KP}=$ Keparahan Penyakit

$\mathrm{n} \quad=$ Jumlah rumpun yang terserang dalam setiap setiap kategori serangan

$\mathrm{v} \quad=$ Kategori (skor) serangan

$\mathrm{N}$ = Jumlah rumpun yang diamati

$\mathrm{Z}$ = Kategori (skor) tertinggi yang digunakan

Skoring penyakit pada tanaman padi ditentukan berdasarkan panduan sistem karakteristik dan evaluasi tanaman padi (diterjemahkan dari Standard Evaluation System (SES) for Rice edisi ke-4, (1996) yang dapat dilihat pada Tabel 1, 2, dan 3 .

\section{HASIL DAN PEMBAHASAN}

Pada tanaman padi ditemukan beberapa penyakit yang disebabkan oleh cendawan, diantaranya adalah penyakit blas yang disebabkan oleh cendawan Pyricularia oryzae Cav., penyakit hawar pelepah yang disebabkan jamur Rhizoctonia solani Khun., dan

Tabel 1. Skoring penyakit blas

\begin{tabular}{cl}
\hline Kategori (skor) & \multicolumn{1}{c}{ Keterangan } \\
\hline 0 & Tidak ada gejala penyakit \\
1 & Gejala belum terlihat jelas \\
2 & Gejala $<5 \%$ dalam satu rumpun \\
3 & Gejala $=5 \%-<25 \%$ dalam satu rumpun \\
4 & Gejala $=25 \%-50 \%$ dalam satu rumpun \\
5 & Gejala $=50 \%$ dalam satu rumpun \\
\hline
\end{tabular}


Tabel 2. Skoring penyakit bercak daun cercospora

\begin{tabular}{cl}
\hline Kategori (skor) & \multicolumn{1}{c}{ Keterangan } \\
\hline 1 & Gejala $<1 \%$ dalam satu rumpun \\
3 & Gejala 1-5\% dalam satu rumpun \\
5 & Gejala 6-25\% dalam satu rumpun \\
7 & Gejala 26-50\% dalam satu rumpun \\
9 & Gejala 51-100\% dalam satu rumpun \\
\hline
\end{tabular}

Tabel 3. Skoring penyakit hawar pelepah daun

\begin{tabular}{cl}
\hline Kategori (skor) & \multicolumn{1}{c}{ Keterangan } \\
\hline 0 & Tidak ada gejala penyakit \\
1 & Gejala $<20 \%$ dalam satu rumpun \\
3 & Gejala 20-30\% dalam satu rumpun \\
5 & Gejala 31-45\% dalam satu rumpun \\
7 & Gejala 46-65\% dalam satu rumpun \\
\hline
\end{tabular}

Tabel 4. Pengaruh fungisida berbahan aktif asam kloro bromo isosianurik terhadap intensitas penyakit blas daun.

\begin{tabular}{lccccc}
\hline \multirow{2}{*}{ Konsentrasi } & \multicolumn{5}{c}{ Rerata intensitas penyakit (\%) pada minggu ke- } \\
\cline { 2 - 6 } & $9 \mathrm{mst}$ & $10 \mathrm{mst}$ & $11 \mathrm{mst}$ & $12 \mathrm{mst}$ & $13 \mathrm{mst}$ \\
\hline Kontrol $\left(0 \mathrm{~g} \mathrm{~L}^{-1}\right)$ & 8,5 & 14,0 & 15,0 & 27,5 & 29,0 \\
$0,5 \mathrm{~g} \mathrm{~L}^{-1}$ & 10.5 & 12,0 & 14,5 & 25,5 & 26,0 \\
$1,0 \mathrm{~g} \mathrm{~L}^{-1}$ & 7,0 & 8,0 & 10,5 & 20,5 & 25,0 \\
$1, \mathrm{~g} \mathrm{~L}^{-1}$ & 9,5 & 14,0 & 14,5 & 22,5 & 22,5 \\
\hline Ni lai F & 0,05 & $0,53^{\text {th }}$ & $0,22^{\text {th }}$ & $0,32^{\text {tn }}$ & $0,23^{\text {tn }}$ \\
BNT & 15,37 & 17,11 & 21,01 & 25,52 & 25,99 \\
\hline
\end{tabular}

Keteragan : $\mathrm{mst}=$ minggu setelah tanam; ${ }^{\mathrm{tn}}=$ tidak berbeda nyata pada taraf $5 \%$.

penyakit bercak daun cercospora yang disebabkan oleh jamur Cercospora oryzae Miyake.

Pengamatan gejala penyakit blas pada daun dilakukan mulai dari sembilan minggu setelah tanam hingga 13 minggu setelah tanam. Hasil analisis ragam menunjukkan bahwa perlakuan fungisida tidak berpengaruh nyata terhadap intensitas penyakit blas daun (Tabel 4).

Berdasarkan data intensitas penyakit blas daun dapat diketahui bahwa perlakuan fungisida berbahan aktif asam kloro bromo isosianurik dari waktu ke waktu tidak menunjukkan pengaruh yang nyata dalam mengendalikan penyakit blas daun. Hasil penelitian ini tidak sejalan dengan hasil penelitian Wibowo (2010) yang dilakukan di Cianjur dan Karawang, yang menunjukkan bahwa pemberian fungisida berbahan aktif asam kloro bromo isosianurik secara nyata efektif mengendalikan penyakit blas daun pada konsentrasi $1,0 \mathrm{~g} \mathrm{~L}^{-1}$ dan juga $1,5 \mathrm{~g} \mathrm{~L}^{-1}$. Perbedaan tersebut diduga karena adanya perbedaaan faktor lingkungan seperti kelembapan udara dan curah hujan yang menyebabkan perbedaan respon tanaman terhadap kemampuan fungisida dalam menekan intensitas penyakit blas daun. Faktor lain yang juga diduga menyebabkan perbedaan hasil penelitian ini adalah kemungkinan berubahnya ras cendawan akibat kondisi lingkungan yang berbeda. Telah dilaporkan bahwa cendawan $P$. oryzae Cav. mempunyai banyak ras fisiologi yang berbeda-beda sifat dan virulensinya. Cendawan ini juga mudah mengadakan mutasi yang menyebabkannya menjadi tahan terhadap fungisida (Dharmaputra, 1985 dalam Semangun, 2004).

Hasil pengamatan menunjukkan bahwa gejala penyakit blas leher malai mulai terlihat pada sebelas minggu setelah tanam (11 mst) sampai dengan pengamatan terakhir yaitu pada tigabelas minggu setelah tanam (13 mst). Pemberian fungisida tidak berpengaruh nyata pada pengamatan 11 dan 12 minggu setelah tanam, 
tetapi tampak pengaruhnya yang nyata pada pengamatan 13 minggu setelah tanam (Tabel 5).

Berdasarkan uji BNT pada taraf 5\%, Tingkat konsentrasi fungisida yang secara nyata dapat menurunkan intensitas penyakit blas leher malai adalah 0,5; 1,0; dan 1,5 $\mathrm{g} \mathrm{L}^{-1}$ walaupun antar perlakuan tidak menunjukkan perbedaan yang nyata. Hasil penelitian Wibowo (2010) juga menunjukkan bahwa perlakuan fungisida berbahan aktif asam kloro bromo isosianurik dapat menurunkan intensitas penyakit blas leher malai secara nyata. Oleh karena itu, didalam pengaplikasian fungisida tersebut dapat digunakan konsentrasi yang paling rendah yaitu $0,5 \mathrm{~g} \mathrm{~L}^{-1}$, karena dengan konsentrasi tersebut sudah dapat mengendalikan penyakit blas leher malai dan hasilnya tidak berbeda nyata dengan konsentrasi 1,0 $\mathrm{g} \mathrm{L}^{-1}$ dan 1,5 $\mathrm{g} \mathrm{L}^{-1}$. Apabila konsentrasi yang digunakan lebih tinggi akan menyebabkan biaya pengeluaran yang lebih tinggi serta pencemaran lingkungan yang ditimbulkan akan lebih tinggi karena bahan kimia yang digunakan lebih banyak.

Perhitungan intensitas penyakit hawar pelepah daun tanaman padi dilakukan berdasarkan pada hasil pengamatan 11 minggu setelah tanam sampai dengan akhir pengamatan yaitu pada 13 minggu setelah tanam. Hasil pengamatan menunjukkan bahwa pemberian fungisida berbahan aktif asam kloro bromo isosianurik tidak berpengaruh nyata terhadap penyakit hawar pelepah daun pada pengamatan minggu ke 11, tetapi berpengaruh nyata pada pengamatan minggu ke 12 dan 13 (Tabel 6).

Pada minggu ke 12 dan 13 (Tabel 6) terlihat bahwa intensitas penyakit hawar pelepah daun pada perlakuan tingkat konsentrasi $0,5 \mathrm{~g} \mathrm{~L}^{-1}$ tidak berbeda nyata dengan kontrol. Tetapi, perlakuan fungisida pada taraf konsentrasi $1,0 \mathrm{~g} \mathrm{~L}^{-1}$ dan $1,5 \mathrm{~g} \mathrm{~L}^{-1}$ secara nyata dapat menurunkan intensitas penyakit hawar pelepah daun,

Tabel 5. Pengaruh fungisida berbahan aktif asam kloro bromo isosianurik terhadap intensitas penyakit blas leher malai

\begin{tabular}{lccc}
\hline \multirow{2}{*}{ Konsentrasi } & \multicolumn{3}{c}{ Rerata intensitas penyakit (\%) pada minggu ke- } \\
\cline { 2 - 4 } & $11 \mathrm{mst}$ & $12 \mathrm{mst}$ & $13 \mathrm{mst}$ \\
\hline Kontrol $\left(\mathrm{g} \mathrm{L}^{-1}\right)$ & 5,3 & 21,3 & $26,7 \mathrm{a}$ \\
$0,5 \mathrm{~g} \mathrm{~L}^{-1}$ & 5,3 & 11,3 & $14,0 \mathrm{~b}$ \\
$1,0 \mathrm{~g} \mathrm{~L}^{-1}$ & 3,3 & 10,7 & $12,7 \mathrm{~b}$ \\
$1,5 \mathrm{~g} \mathrm{~L}^{-1}$ & 4,0 & 6,7 & $8,0 \mathrm{~b}$ \\
\hline Nilai F 0,05 & $0,12^{\text {tn }}$ & $4,59^{\mathrm{tn}}$ & $6,64^{*}$ \\
BNT & 10,06 & 10,08 & 10,72 \\
\hline
\end{tabular}

Keterangan : Nilai-nilai yang diikuti dengan huruf yang sama adalah tidak berbeda nyata berdasarkan Uji BNT pada taraf $5 \%$, mst $=$ minggu setelah tanam, ${ }^{\mathrm{tn}}=$ tidak berbeda nyata pada taraf $5 \%, *$ = berbeda nyata pada taraf $5 \%$.

Tabel 6. Pengaruh fungisida berbahan aktif asam kloro bromo isosianurik terhadap intensitas penyakit hawar pelepah daun.

\begin{tabular}{lccc}
\hline \multirow{2}{*}{ Konsentrasi } & \multicolumn{3}{c}{ Rerata intensitas penyakit (\%) pada minggu ke- } \\
\cline { 2 - 4 } & $11 \mathrm{mst}$ & $12 \mathrm{mst}$ & $13 \mathrm{mst}$ \\
\hline Kontrol $\left(\mathrm{g} \mathrm{L}^{-1}\right)$ & 11,48 & $19,63 \mathrm{a}$ & $19,63 \mathrm{a}$ \\
$0,5 \mathrm{~g} \mathrm{~L}^{-1}$ & 14,07 & $17,41 \mathrm{a}$ & $17,41 \mathrm{a}$ \\
$1,0 \mathrm{~g} \mathrm{~L}^{-1}$ & 5,93 & $8,52 \mathrm{~b}$ & $8,52 \mathrm{~b}$ \\
$1,5 \mathrm{~g} \mathrm{~L}^{-1}$ & 8,15 & $9,26 \mathrm{~b}$ & $9,26 \mathrm{~b}$ \\
\hline Nilai F 0,05 & $4,10^{\mathrm{tn}}$ & $6,87^{*}$ & $6,87^{*}$ \\
BNT & 6,15 & 7,45 & 7,45 \\
\hline
\end{tabular}

Keterangan : Nilai-nilai yang diikuti dengan huruf yang sama adalah tidak berbeda nyata berdasarkan Uji BNT pada taraf 5\%; mst $=$ minggu setelah tanam; ${ }^{\mathrm{tn}}=$ tidak berbeda nyata pada taraf $5 \%$; $*$ berbeda nyata pada taraf $5 \%$. 
Tabel 7. Pengaruh fungisida berbahan aktif asam kloro bromo isosianurik terhadap intensitas penyakit bercak daun cercospora.

\begin{tabular}{lcc}
\hline \multirow{2}{*}{ Konsentrasi } & \multicolumn{2}{c}{ Intensit as Penya kit Cercospora (\%) } \\
\cline { 2 - 3 } & $12 \mathrm{mst}$ & $13 \mathrm{mst}$ \\
\hline Kontrol $\left(\mathrm{g} \mathrm{L}^{-1}\right)$ & 20,34 & 20,34 \\
$0,5 \mathrm{~g} \mathrm{~L}^{-1}$ & 19,04 & 19,59 \\
$1,0 \mathrm{~g} \mathrm{~L}^{-1}$ & 20,61 & 20,83 \\
$1,5 \mathrm{~g} \mathrm{~L}^{-1}$ & 20,19 & 20,63 \\
\hline Ni lai F 0,05 & $0,09^{\mathrm{tn}}$ & $0,07^{\mathrm{tn}}$ \\
BNT & 9,54 & 8,92 \\
\hline
\end{tabular}

Keterangan : $\mathrm{mst}=$ minggu setelah tanam; ${ }^{\mathrm{tn}}=$ tidak berbeda nyata pada taraf $5 \%$.

meskipun antar keduanya tidak berbeda nyata. Hal tersebut diduga karena fungisida berbahan aktif asam kloro bromo isosianurik pada konsentrasi yang rendah ( $\left.0,5 \mathrm{~g} \mathrm{~L}^{-1}\right)$ belum mampu menghambat perkembangan cendawan Rhizoctonia solani Khun. Berdasarkan hal tersebut dapat disimpulkan bahwa pemberian fungisida berbahan aktif asam kloro bromo isosianurik dapat mengendalikan penyakit hawar pelepah daun pada konsentrasi $1,0 \mathrm{~g} \mathrm{~L}^{-1}$ dan $1,5 \mathrm{~g} \mathrm{~L}^{-1}$.

Pengamatan intensitas penyakit bercak daun Cercospora dilakukan pada 12 sampai dengan 13 minggu setelah tanam. Hasil pengamatan menunjukkan bahwa intensitas penyakit pada setiap perlakuan tidak berbeda nyata baik pada minggu ke 12 maupun pada minggu ke 13 (Tabel 7).

Hasil penelitian ini menunjukkan bahwa fungisida berbahan aktif asam kloro bromo isosianurik tidak efektif dalam mengendalikan penyakit bercak daun cercospora. Senyawa aktif dalam fungisida tersebut tidak mampu menekan cendawan Cercospora oryzae Miyake penyebab penyakit bercak daun cercospora. Agrios (2005) menyatakan bahwa jenis cendawan patogen tertentu hanya dapat dikendalikan oleh senyawa kimia tertentu. Bila suatu senyawa kimia tertentu diaplikasikan pada suatu tanaman, maka reaksi tanaman terhadap senyawa kimia tersebut akan mempengaruhi pula penghambatan pertumbuhan patogen dalam tanaman. Atas dasar itu, diduga bahwa fungisida berbahan aktif asam kloro bromo isosianurik tidak mampu menghambat pertumbuhan cendawan Cercospora oryzae sehingga tidak menekan intensitas penyakit.

Fungisida yang diuji disini tampaknya belum mampu mengendalikan cendawan penyebab penyakit penyakit blas daun dan penyakit bercak daun cercospora, tetapi efektif dalam mengendalikan cendawan penyebab penyakit blas leher dan penyakit hawar pelepah daun. Hal tersebut diduga berkaitan dengan sifat fungisida tersebut yang merupakan fungisida sistemik yang bersifat akropetal yakni fungisida tersebut masuk melalui daun menuju akar tanaman kemudian dari organ akar ditranslokasikan ke bagian batang lalu ke bagian daun tanaman (Subiyakto dan Kartono, 1998 dalam Lestari dan Suryanto, 2012). Apabila suatu senyawa kimia tertentu diaplikasikan pada suatu tanaman, reaksi yang terjadi di dalam sel atau jaringan tanaman tersebut mampu menghasilkan senyawa toksin terhadap patogen (Agrios, 2005).Berdasarkan hal tersebut diduga bahwa senyawa toksin yang terjerap dibagian batang tanaman lebih banyak dibandingkan senyawa toksin yang terjerap pada bagian daun tanaman padi. Distribusi senyawa toksin didalam sistem pembuluh tanaman terlebih dahulu melalui bagian batang, sehingga fungisida tersebut lebih efektif mengendalikan penyakit yang ada di bagian tanaman padi.

\section{KESIMPULAN}

Aplikasi fungisida berbahan aktif asam kloro bromo isosianurik efektif menekan intensitas penyakit blas leher dan penyakit hawar pelepah daun tetapi tidak efektif menekan intensitas penyakit blas daun dan penyakit bercak daun cercospora pada tanaman padi varietas Ciherang di Lampung. Tingkat konsentrasi fungisida yang efektif menekan intensitas penyakit blas leher adalah 0,$5 ; 1,0$; dan $1,5 \mathrm{~g} \mathrm{~L}^{-1}$ sedangkan tingkat konsentrasi fungisida yang efektif menekan intensitas penyakit hawar pelepah daun adalah $1,0 \mathrm{~g} \mathrm{~L}^{-1}$ dan $1,5 \mathrm{~g}$ $\mathrm{L}^{-1}$.

\section{DAFTAR PUSTAKA}

Agrios, N.G. 2005. Plant Pathology- Fifth Edition. Departemen of Plant Pathology. University of Florida. United States of America. 
Anonim. 2010. Agent for Preventing and Treating Colletotrichum gloesporiodes and Preparation MethodeThereof. 18 Mei 2011. IP. com. dalam: http://ip.com/patfam/en43992598. Diakses tanggal 20 Desember 2012.

Dahyar, A.Rugaya dan A. K. Parawansah. 2010. Efektivitas bakteri antagonis Corynebacterium sp terhadap penyakit blas (Pyricularia grisea Sacc) pada tanaman padi. Prosiding Seminar Ilmiah dan Pertemuan Tahunan PEI dan PFI XX Komisariat Daerah Sulawesi Selatan, 27 Mei 2010.

Djojosumarto, P. 2000. Teknik Aplikasi Pestisida Pertanian. Kanisius. Yogyakarta.

Kegley, SE, BR. Hill, S. Orme \& AH. Choi 2010. Bromo chloro isocyanuric acid - Identification , toxicity, use, water pollution potential, ecological toxicity and regulatory information. PAN Pesticide Database Chemicals. Dalam: http:/ / www.pesticideinfo.org/Detail_. Diakses tanggal 20 Desember 2012.
Lestari. F dan E. Suryanto. 2012. Efikasi Bacillus thuringiensis terhadap hama ulat daun gaharu Heortia vitessoides. Balai Penelitian Kehutanan Banjarbaru. Kalimantan Selatan.Semangun, H. 2004. Penyakit Penyakit Tanaman Pangan di Indonesia. Gadjah Mada University Press. Yogyakarta.

Semangun, H. 2004. Penyakit-penyakit Tanaman Pangan di Indonesia. Gadjah Mada University Press. Yogyakarta..

Wibowo, B.S 2010. Karakteristik penyakit blas dan hawar daun bakteri (HBD) dan hasil pengujian. Balai Besar Peramalan Organisme Pengganggu Tumbuhan(BBPOPT). Jatisari. 